\title{
Physical and chemical characterization of African catfish smoked sausage with different liquid smoke concentrations and immersion durations
}

\author{
Ernawati $^{1}$, Moh. Awaludin Adam ${ }^{2,3^{*}}$, Irawati Mei Widiastuti ${ }^{4}$, and Era Insivitawati ${ }^{5}$ \\ ${ }^{1}$ Technology of Fisheries Product, Faculty of Agriculture, University of Yudharta, Pasuruan, East \\ Java, Indonesia \\ ${ }^{2}$ Reseacrh Center for Limnology, National Research and Inovation Agency (BRIN), Cibinong, \\ Indonesia \\ ${ }^{3}$ Faculty of Science and Technology, University of Ibrahimy, Situbondo, Indonesia \\ ${ }^{4}$ Aquaculture, Faculty of Animal Husbandry and Fisheries, University of Tadulako, Palu, Central \\ Sulawesi, Indonesia \\ ${ }^{5}$ Polytechnics of Marine and Fisheries, KKP, Sidoarjo, East Java, Indonesia
}

\begin{abstract}
Product diversification is needed to increase selling and marketing prices. One of them is the African catfish sausage product. Liquid smoke has been used commercially by the food industry. This study aimed to determine the physical and chemical properties of smoked African catfish after adding different concentrations of liquid smoke and immersion duration. The chemical analysis measured the levels of protein, fat, and phenol. The results showed that sausage with a concentration of $20 \%$ liquid and soaking for 30 minutes was the best treatment with a protein content of $43.8 \pm 0.34 \%$, a fat of $12.33 \pm 0.61 \%$, and phenol $292.74 \mathrm{ppm}$. Determination of the compound using GC-MS found that the most dominant compound in the smokeless sausage was 2-hexanone, 3,3 dimethyl with a relative concentration of $32.42 \%$. The dominant compound in the besttreated sausage was Furan, tetrahydro-2,2-dimethyl- with a relative concentration of $19 \%$. Liquid smoke penetration is clearly visible in the microstructure of smoked sausages, both in the best-treated smoked sausages and commercial sausages. Scanning Electron Microscope (SEM) magnification of 2.500x shows that the best emulsified smoked sausages have a flatter structure, smaller droplets, and are more refined than smokeless sausages or commercial smoked sausages.
\end{abstract}

\section{Introduction}

African catfish (Clarias gariepinus) is an inland fishery product as an animal protein source. This fish has a reasonably high production potential. The Ministry of Maritime Affairs and

*Corresponding author: moha067@lipi.go.id 
Fisheries (KKP) reported that the realization of national catfish production reached 400 thousand tons until the end of 2020 [1]. The marketing of African catfish in a fresh state is still profitable. However, when production is expected to be abundant for the next few years, product diversification efforts are needed to increase the selling price and marketing [2]. One of the businesses of processing African catfish is smoked sausage of African catfish using liquid smoke [3].

Sausage comes from the Latin "salsus" which means salted or is meat prepared through salting [4]. Sausage is meat made from mashed, grind, seasoned, and then wrapped in an asymmetrically shaped casing and has a distinctive taste [5]. Sausage is an alternative diversification of food processing, which has a high nutritional content, made from meat, both from marine fish and freshwater fish [6]. Sausage processing was initially very simple with just salting and drying. However, recently sausage making has been developed by adding spices and seasonings based on conditions of the original area. There are several different ways of making sausages to produce distinctive flavors, textures and shapes based on their regional origin, for example by curing, boiling, smoking, or fermentation [7].

Smoking technology using liquid smoke has now been developed to produce a product with a more uniform flavor than the traditional methods. Liquid smoke is a natural aqueous condensation from wood that has undergone aging and filtration to separate tar compounds and certain materials [8]. Identified components of liquid smoke mainly come from the thermal degradation of wood carbohydrates such as ketones, carbonyls, acids, furans, and pyran derivatives. In addition, this liquid smoke also contains components derived from the thermal degradation of lignin, such as phenol, guaiacol, and its derivatives, syringol and its derivatives, and alkyl aryl [9].

It is further stated that phenol is the highest proportion component at $14.87 \%$. Meanwhile, according to [10], the pyrolysis of cellulose, hemicellulose, and lignin compounds will produce organic acids, phenols, and carbonyls, which play a role in food preservation. Currently, liquid smoke has been used commercially by the food industry [11]. Liquid smoke can be added directly to the surface of the product by immersion, spraying, or atomization [12]. The use of liquid smoke in food products has several advantages compared to traditional smoking, including saving costs for wood and smoke-making equipment, adjusting the flavor of the product as desired, reducing harmful components (benzo compounds (a) pyrene, which is carcinogenic, be widely used in foods where traditional methods cannot overcome its, be applied to ordinary people, reduce air pollution and the composition of liquid smoke is more consistent for repeated use $[4,12,13]$.

Research on the sensory and microstructure properties of African catfish sausage treated with liquid smoke is needed considering that liquid smoke has been used commercially by the food industry currently [14]. Smoking technology using liquid smoke can produce a product with a more uniform flavor compared to traditional methods. This alternative will be more varied on the people's food menu, types, nutrition, and affordable price. Therefore, this study aims to characterize African catfish smoked sausage's physical and chemical structure after adding different concentrations of liquid smoke and immersion duration. Furthermore, it becomes a recommendation for the use of raw materials for fish sausage products.

\section{Materials and methods}

This research was conducted at the Laboratory of Agricultural Products Technology, Faculty of Agricultural Technology, University of Brawijaya Malang, Integrated Research and Development Laboratory (LPPT) Gadjah Mada University Yogyakarta, Laboratory of Organic Chemistry, Faculty of Mathematics and Natural Sciences, Gadjah Mada University Yogyakarta, Electron Microscope Laboratory and Integrated Medical Faculty of Medicine Airlangga University Surabaya, and Central Laboratory of the Faculty of Mathematics and 
Natural Sciences, State University of Malang. The study was carried out from November 2019 to June 2020.

\subsection{Materials}

The main ingredient used in this study was African catfish (Clarias gariepinus) with a consumption size (6-7 fish/kg) obtained from catfish farmers in Sumberwaras Lawang, Malang City. Redistilled liquid smoke from coconut shells was obtained from the Laboratory of Food Technology and Agricultural Products, Faculty of Agricultural Technology, Gadjah Mada University, Yogyakarta. The chemicals used for the analysis were obtained from the Laboratory of Agricultural Products Technology and CV Dian Pharmacy Malang. Chemicals with pro analysis (p.a) specifications are Folin-Ciocalteu, $\mathrm{Na}_{2} \mathrm{CO}_{3}$, gallic acid, all from Merck were used for total phenol analysis; $\mathrm{Na}_{2} \mathrm{SO}_{4}, \mathrm{Na}_{2} \mathrm{~S}_{2} \mathrm{O}_{3} \mathrm{H}_{2} \mathrm{SO}_{4}, \mathrm{NaOH}$ (technical purity), $\mathrm{NaOH}$ (p.a), HCl, Kjeldahl tablets, phosphate buffer, sand, petroleum ether (p.a), methyl red indicator; Distilled water was used as analytical material with technical purity. The tools used in this study were a dry blender (Panasonic) with a blade turning motor speed of $1800 \mathrm{rpm}$, a thermometer measuring $360^{\circ} \mathrm{C}$. The tools used in the analysis were digital scales (XP-1500, Germany), vortex (Barnstead), centrifuge (EBA 20), Thermostirre, Magnetic Stirrer $3 \mathrm{~cm}$ and filter paper (Whatman No.42, UV-2100 spectrophotometer (Unico), test tube (Pyrex), 50 $\mathrm{ml}$ measuring cup (Pyrex), $250 \mathrm{ml}$ Erlenmeyer (Pyrex), $100 \mathrm{ml}$ volumetric flask (Pyrex), 101001 micropipette (Soccorex), pipette $1 \mathrm{ml}$ volume (Assistance), $5 \mathrm{ml}$ volumetric pipette (HBG), $250 \mathrm{ml}$ beaker glass (Pyrex), $100 \mathrm{ml}$ separating funnel (Schott-Duran), wooden test tube rack, bubble Suck, burette, spatula, long spatula, a set of Kjeldahl tools, distillation apparatus, MMM Medcenter oven, Soxhlet tube, penetrometer, Gas Chromatography-Mass Spectrometry QP2010 (Shimadzu, Japan), and Scanning Electron Microscopy (SEM) FEI The Inspect S-50 type was used to obtain microstructural images of smoked African catfish sausages.

\subsection{Methods}

\subsubsection{Catfish sausage preparation}

The preparation stage for African catfish consisted of weeding, washing, and separating the fish flesh from the bones. Fish meat is mashed with a chopper $\pm 1-2$ minutes, mixed with salt and ice water using a mixer for 0.5 minutes, put in the spices that have been mashed, tapioca flour 5\% (w/w), 6\% skim milk, then coconut oil $(3 \% \mathrm{w} / \mathrm{w})$. The dough is stirred until homogeneous. The dough is put into a plastic casing with a diameter of $2.5 \mathrm{~cm}$, and then the sausage is tied along $10 \mathrm{~cm}$ and steamed for 30 minutes. Sausage is cooled at room temperature by means of aerated. Sausage is opened in its casing. Sausage is soaked in liquid smoke, respectively $15 \%, 20 \%, 25 \%$. The immersion time is 15 minutes, 30 minutes, and 45 minutes. Next, the sausage is heated in an oven at $60{ }^{\circ} \mathrm{C}$ for 3 hours. The combination treatment was analyzed and observed, and the best treatment was taken.

\subsubsection{Observation of research parameters}

Observations were performed on the African catfish smoked sausage products after being treated with a certain concentration of liquid smoke and a certain immersion duration and the fatty acid stability of African catfish sausage during storage. Observations on liquid smoke consisted of components of liquid smoke compounds using GC-MS [15, 16], antioxidant activity using DPPH [17, 18], and analysis of phenol levels [19]. Observations on African 
catfish that will be used as raw material for sausages included water content, fat content, $A_{W}$ content, and fatty acid profile [20. Sausage microstructural observations using SEM [21] were carried out before the sausage was subjected to liquid smoke immersion treatment and after obtaining the best treatment and commercial smoked fish sausage samples as a comparison. Chemical analysis used as a support for sausage microstructure is texture analysis using the penetrometer method, water content, and $A_{W}$ value. The best treatment has been analyzed the components of compounds in sausages and the presence of PAHs using GC-MS [22].

\subsubsection{Observation of the microstructure of catfish sausage}

Microstructural observations were conducted on smokeless sausage, the best treatment of smoked sausage, and certain commercial smoked fish sausages brands as a comparison. Meanwhile, to support the analysis, the $A_{W}$ content and texture analysis were carried out using the penetrometer method $[23,24]$ on those three samples.

\subsection{Data analysis}

The data obtained during the study were statistically analyzed using factorial analysis of variance (ANOVA) and processed using "Microsoft Excel". If the results of ANOVA significantly affect the interaction of the two treatments, DMRT test will be processed with $\alpha>5 \%$ confidence interval. The effectiveness index was used for the determination of the best treatment. CMS was used for data analysis of liquid smoke and smoked sausage components. SEM was applied for sausage microstructures and discussed descriptively based on the literature.

\section{Results}

\subsection{Fat content of African catfish smoked sausage}

The average fat content of catfish sausage ranged from $11.34 \%$ to $12.89 \%$ (dw). These results are presented in Table 1.

Table 1. Average fat content ( $\% \mathrm{dw})$ of catfish smoked sausage with differences in liquid smoke concentration and immersion duration.

\begin{tabular}{ccc}
\hline $\begin{array}{c}\text { Liquid smoke concentration } \\
(\%)\end{array}$ & $\begin{array}{c}\text { Duration of immersion } \\
\text { (minutes) }\end{array}$ & $\begin{array}{c}\text { Average fat content } \\
(\% \mathrm{dw})\end{array}$ \\
\hline \multirow{2}{*}{15} & 15 & $11.37 \pm 0.89$ \\
& 30 & $12.22 \pm 0.73$ \\
20 & 45 & $11.34 \pm 0.43$ \\
\hline \multirow{2}{*}{20} & 15 & $11.78 \pm 0.82$ \\
& 30 & $12.32 \pm 0.61$ \\
& 45 & $12.89 \pm 0.39$ \\
\hline \multirow{2}{*}{25} & 15 & $11.61 \pm 0.94$ \\
& 30 & $12.85 \pm 0.37$ \\
\end{tabular}

Note : Each data is an average of 3 replications \pm standard deviation 


\subsection{Protein content of African catfish smoked sausage}

The average protein content of smoked catfish sausage ranged from $42,96 \%$ to $43.88 \%$ (dw), which is presented in Table 2 .

Table 2. Average protein content ( $\% \mathrm{dw}$ ) of catifsh smoked sausage with differences in liquid smoke concentration and immersion duration.

\begin{tabular}{lll}
\hline $\begin{array}{c}\text { Liquid smoke concentration } \\
(\%)\end{array}$ & $\begin{array}{c}\text { Duration of immersion } \\
\text { (minutes) }\end{array}$ & $\begin{array}{c}\text { Average protein content } \\
(\% \mathrm{dw})\end{array}$ \\
\hline & 15 & $43.88 \pm 0.39$ \\
15 & 30 & $43.56 \pm 0.61$ \\
& 45 & $42.96 \pm 0.48$ \\
\hline & 15 & $43.26 \pm 0.30$ \\
20 & 30 & $43.87 \pm 0.34$ \\
& 45 & $43.34 \pm 0.47$ \\
\hline & 15 & $43.35 \pm 0.47$ \\
& 30 & $43.45 \pm 0.45$ \\
& 45 & $43.67 \pm 0.68$ \\
\hline
\end{tabular}

Note : Each data is an average of 3 replications \pm standard deviation

\subsection{Phenol content of African catfish smoked sausage}

Phenol compounds results are presented in Table 3.

Table 3. Average phenol levels (ppm) of catfish smoked sausage with differences in liquid smoke concentration and immersion duration.

\begin{tabular}{cccc}
\hline $\begin{array}{c}\text { Liquid smoke } \\
\text { concentration (\%) }\end{array}$ & $\begin{array}{c}\text { Duration of } \\
\text { immersion } \\
\text { (minutes) }\end{array}$ & $\begin{array}{c}\text { Average phenol } \\
\text { content } \\
(\mathrm{ppm})\end{array}$ & DMRT 1\% \\
\hline \multirow{2}{*}{15} & 15 & $234.92^{\mathrm{a}}$ & \\
& 30 & $256.16^{\mathrm{b}}$ & \\
\hline \multirow{2}{*}{20} & 45 & $291.22^{\mathrm{e}}$ & \\
& 15 & $273.00^{\mathrm{c}}$ & \\
\hline \multirow{2}{*}{25} & 30 & $294.62^{\mathrm{f}}$ & \\
& 45 & $347.59^{\mathrm{h}}$ & \\
\hline & 15 & $280.81^{\mathrm{d}}$ & \\
\hline
\end{tabular}

Note: Values accompanied by different notations show a significant difference in $1 \%$ DMRT $(0.867-$ $0.985)$

\subsection{Best treatment based on the effectiveness index}

The total value of the best treatment determination from different concentrations of liquid smoke and immersion time are presented in Table 4. 
Table 4. Total value of the best treatment determination.

\begin{tabular}{ccc}
\hline & Treatment & Result value \\
\hline $\begin{array}{c}\text { Liquid smoke } \\
\text { concentration (\%) }\end{array}$ & $\begin{array}{c}\text { Duration of immersion } \\
\text { (minute) }\end{array}$ & 0,47 \\
\multirow{2}{*}{15} & 15 & 0,34 \\
& 30 & $0,66^{2}$ \\
\hline \multirow{2}{*}{20} & 45 & $0,54^{3}$ \\
& 15 & $0,67^{1}$ \\
25 & 30 & 0,53 \\
\hline \multirow{2}{*}{25} & 45 & 0,47 \\
& 15 & 0,43 \\
& 30 & 0,48 \\
\hline
\end{tabular}

The data in Table 4. shows that the best treatment combination was obtained from the treatment of $20 \%$ liquid smoke concentration and 30 minutes of immersion.

\subsection{Component analysis of catfish smoked sausage using GC-MS}

The results of the best treatment (liquid smoke 20\%, immersion 30 minutes) components were identified using GC-MS, and African catfish sausages that were not smoked were also analyzed for their components as a comparison. The GC chromatogram results of smokeless sausage (control) and smoked sausage with the best treatment are presented in Fig. 1. Meanwhile, the results of Mass Spectrum (MS) of the dominant compound in smokeless sausage and smoked sausage with the best treatment are presented in Fig. 2 and Fig. 3.

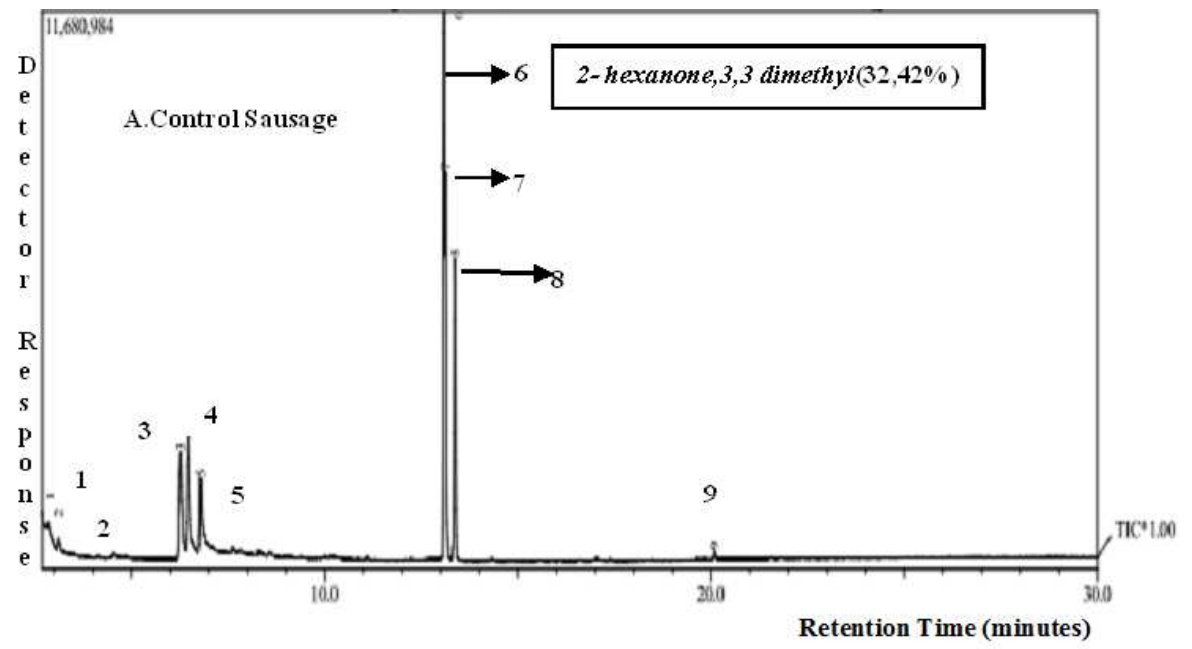




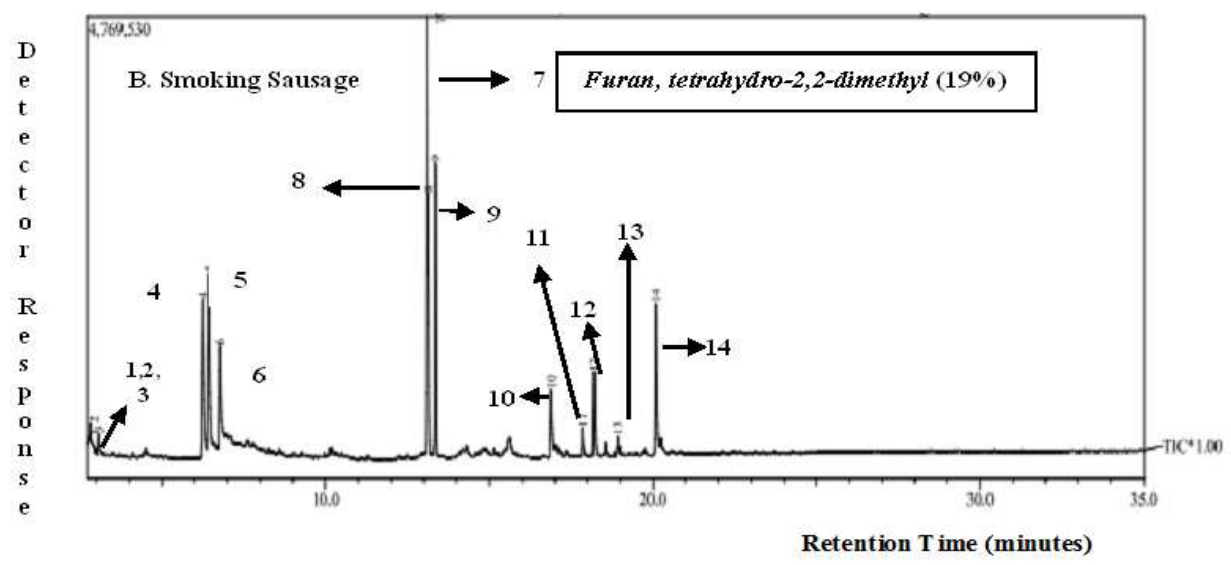

Fig. 1. GC-MS Chromatogram of smokeless sausage (Control) and the best treated smoked sausage. $\mathrm{A}=$ control sausage $\mathrm{B}=$ smoking sausage

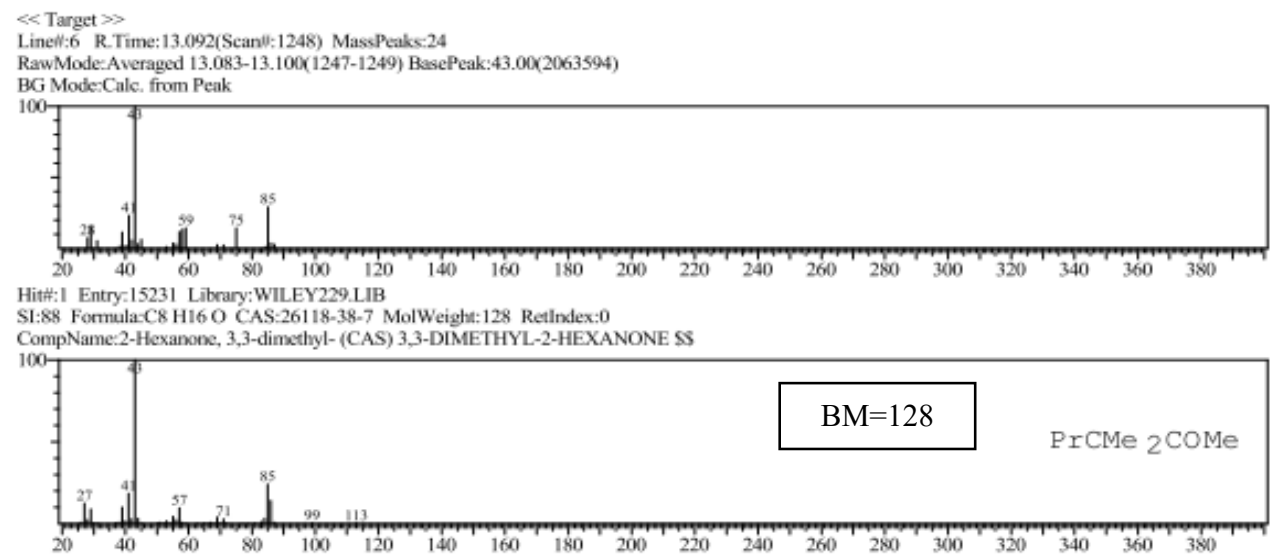

Fig. 2. Mass spectrum 2-hexanone, 3,3 dimethyl (peak 6) as the dominant compound in smokeless sausage

$\ll$ Target $\gg$

Linell:7 R.Time: 13.083(Scant: 1247) MassPeaks:25

RawMode:Averaged 13.075-13.092(1246-1248) BasePeak:43.05(847978)

BG Mode:Calc, from Penk

100 f

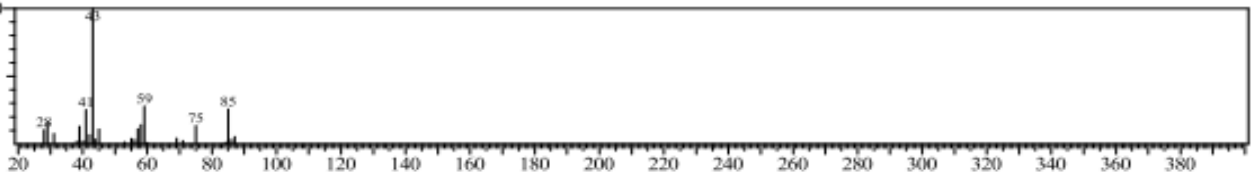

Hitu:1 Entry-5561 Library WILEY229,LIB

SI:86 Formula-C6 H12 O CAS:1003-17-4 MolWeight:100 RetIndex:0

CompName:FURAN, TETRAHYDRO-2,2-DIMETHYL- \$S

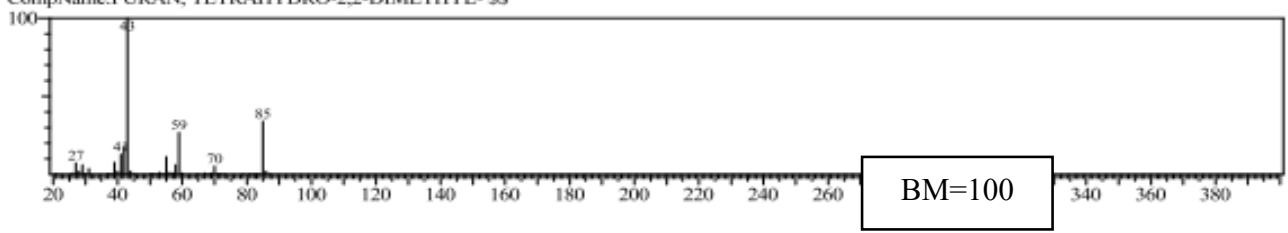

Fig. 3. Mass spectrum furan, tetrahydro-2-2-dimethyl (peak 7) as the dominant compound in the best treated smoked sasage 
The most dominant compounds from smokeless sausages (control) can be seen in Table 5 .

Table 5. Compound composition of smokeless catfish sausage (control) using GC-MS

\begin{tabular}{|c|c|c|c|c|c|c|}
\hline No & $\begin{array}{l}\text { Retenti } \\
\text { on } \\
\text { Time }\end{array}$ & $\begin{array}{l}\text { Molecu- } \\
\quad \text { lar } \\
\text { Formula }\end{array}$ & $\begin{array}{c}\text { Molec } \\
\text { ular } \\
\text { Weig } \\
\text { ht }\end{array}$ & IUPAC Name & $\begin{array}{l}\text { Group } \\
\text { Compound }\end{array}$ & $\begin{array}{c}\text { Relative } \\
\text { concentrati } \\
\text { on }(\%)\end{array}$ \\
\hline 1 & 2.843 & $\mathrm{C}_{8} \mathrm{H}_{16}$ & 112 & $\begin{array}{l}\text { Cyclohexane, 1,4-dimethyl-, } \\
\text { cis-4-dimethylcyclohexane }\end{array}$ & carbonyl & 0.51 \\
\hline 2 & 3.118 & $\mathrm{C}_{9} \mathrm{H}_{18}$ & 126 & $\begin{array}{l}\text { Cyclopentane, 1-methyl-3- } \\
\text { (1-methylethyl) }\end{array}$ & Ketones & 0.82 \\
\hline 3 & 6.266 & $\mathrm{C}_{6} \mathrm{H}_{14} \mathrm{O}$ & 102 & 2-butanol,2,3-dimethyl & Alcohol & 10.79 \\
\hline 4 & 6.463 & $\mathrm{C}_{6} \mathrm{H}_{14} \mathrm{O}$ & 102 & 2-pentanol, 2-methyl & Alcohol & 11.92 \\
\hline 5 & 6.786 & $\mathrm{C}_{6} \mathrm{H}_{14} \mathrm{O}$ & 102 & 3-methyl-3-pentanol & Alcohol & 7.36 \\
\hline 6 & 13.089 & $\mathrm{C}_{8} \mathrm{H}_{16} \mathrm{O}$ & 128 & 2-hexanone, 3,3 dimethyl & Ketones & 32.42 \\
\hline 7 & 13.131 & $\mathrm{C}_{5} \mathrm{H}_{8} \mathrm{O}_{2}$ & 100 & Acetic acid, 2-propyl ester & Acid & 18.39 \\
\hline 8 & 13.368 & $\mathrm{C}_{6} \mathrm{H}_{12} \mathrm{O}$ & 100 & 2-pentanone, 3-methyl- & Ketones & 17.25 \\
\hline 9 & 20.090 & $\mathrm{C}_{15} \mathrm{H}_{26} \mathrm{O}$ & 222 & patchouli alcohol, & Terpene & 0.54 \\
\hline
\end{tabular}

6.

The compounds identified in the best treatment of smoked sausages can be seen in Table

Table 6. Composition of smoked sausage compound with the best treatment.

\begin{tabular}{|c|c|c|c|c|c|c|}
\hline No & $\begin{array}{l}\text { Retentio } \\
\text { n Time }\end{array}$ & $\begin{array}{l}\text { Molecula } \\
\text { r } \\
\text { Formula }\end{array}$ & $\begin{array}{l}\text { Molecu } \\
\text { lar } \\
\text { Weight }\end{array}$ & IUPAC Name & $\begin{array}{l}\text { Group } \\
\text { Compound }\end{array}$ & $\begin{array}{c}\text { Relative } \\
\text { Concentra } \\
\text { tion }(\%)\end{array}$ \\
\hline 1 & 2.750 & $\mathrm{C}_{8} \mathrm{H}_{16}$ & & $\begin{array}{l}\text { Cyclohexane, 1,2-dimethyl- } \\
\text {, trans- }\end{array}$ & Carbonyl & 0.37 \\
\hline 2 & 2.809 & $\mathrm{C}_{8} \mathrm{H}_{16}$ & & $\begin{array}{l}\text { Cyclohexane, 1,4-dimethyl- } \\
\text {, cis- }\end{array}$ & Carbonyl & 1.23 \\
\hline 3 & 3.077 & $\mathrm{C}_{9} \mathrm{H}_{18}$ & & $\begin{array}{l}\text { Cyclopentane, 1-methyl- } \\
3(1-\text {-methylethyl) }\end{array}$ & Carbonyl & 1.06 \\
\hline 4 & 6.234 & $\mathrm{C}_{6} \mathrm{H}_{14} \mathrm{O}$ & & 2-butanol,2,3-dimethyl & Alcohol & 12.87 \\
\hline 5 & 6.432 & $\mathrm{C}_{6} \mathrm{H}_{14} \mathrm{O}$ & & 2-pentanol, 2-methyl- & Alcohol & 13.50 \\
\hline 6 & 6.757 & $\mathrm{C}_{6} \mathrm{H}_{14} \mathrm{O}$ & & 3-methyl-3 pentanol & Alcohol & 7.77 \\
\hline 7 & 13.082 & $\mathrm{C}_{6} \mathrm{H}_{12} \mathrm{O}$ & & $\begin{array}{l}\text { Furan, tetrahydro-2,2- } \\
\text { dimethyl- }\end{array}$ & Furan & 19.00 \\
\hline 8 & 13.124 & $\mathrm{C}_{5} \mathrm{H}_{10} \mathrm{O}$ & & 2-butanone, 3-methyl- & Ketones & 9.98 \\
\hline 9 & 13.360 & $\mathrm{C}_{6} \mathrm{H}_{12} \mathrm{O}$ & & $\begin{array}{l}\text { 2-pentanone, 3-methyl-2- } \\
\text { pentanone }\end{array}$ & Ketones & 12.89 \\
\hline 10 & 16.895 & $\mathrm{C}_{7} \mathrm{H}_{8} \mathrm{O}_{2}$ & & Phenol, 2-methoxy- & Phenol & 4.45 \\
\hline 11 & 17.851 & $\mathrm{C}_{8} \mathrm{H}_{10} \mathrm{O}_{2}$ & & Benzene, 1,4-dimethoxy- & $\begin{array}{l}\text { Alkyl aryl } \\
\text { ether }\end{array}$ & 1.73 \\
\hline 12 & 18.204 & $\mathrm{C}_{6} \mathrm{H}_{6} \mathrm{O}$ & & $\begin{array}{l}\text { Phenol, benzenol, } \\
\text { oxybenzene }\end{array}$ & Phenol & 5.05 \\
\hline 13 & 18.925 & $\mathrm{C}_{8} \mathrm{H}_{10} \mathrm{O}$ & & Phenol, 2,3-dimethyl- & Phenol & 0.94 \\
\hline 14 & 20.084 & $\mathrm{C}_{15} \mathrm{H}_{26} \mathrm{O}$ & & Patchouli alcohol & Terpene & 9.16 \\
\hline
\end{tabular}

\subsection{Catfish sausage microstructure}

The samples of African catfish sausages observed for microstructures included: smokeless African catfish sausages, smoked sausages with the best treatment, and sure commercial smoked fish sausages. The commercial smoked fish sausage was used as a comparison. Using a penetrometer, the three samples were then analyzed for moisture content, $A_{W}$ value, and 
texture values. The analysis results of the three samples, including water content, $A_{W}$ value, and texture value using a penetrometer, are presented in Table 7.

Table 7. Analysis of moisture content, Aw value, and fish sausage texture.

\begin{tabular}{lllcc}
\hline No & \multicolumn{1}{c}{ Sample type } & $\begin{array}{c}\text { Moisture } \\
\text { content }(\%)\end{array}$ & Aw Value & $\begin{array}{c}\text { Texture } \\
(\mathrm{mm} / \mathrm{g} . \mathrm{dtk})\end{array}$ \\
\hline 1 & Smokeless sausage & $62.59 \pm 0.29$ & $0.85 \pm 0.04$ & $2.65 \pm 0.07$ \\
2 & $\begin{array}{l}\text { The best treatment } \\
(20 \% \text { for 30') }\end{array}$ & $62.56 \pm 0.02$ & $0.83 \pm 0.02$ & $2.35 \pm 0.07$ \\
3 & $\begin{array}{l}\text { Commercial smoked } \\
\text { sausage }\end{array}$ & $67.86 \pm 0.54$ & $0.88 \pm 0.03$ & $2.95 \pm 0.07$ \\
\hline
\end{tabular}

Results of Observations of the microstructure of African catfish sausage and commercial smoked fish sausage are presented in Fig. 4.

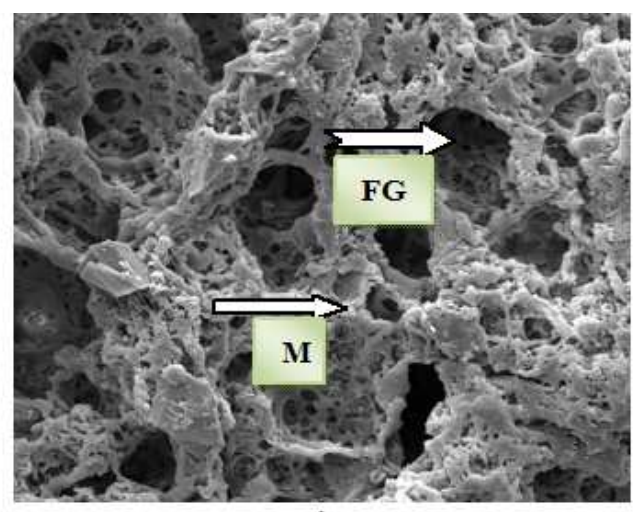

A

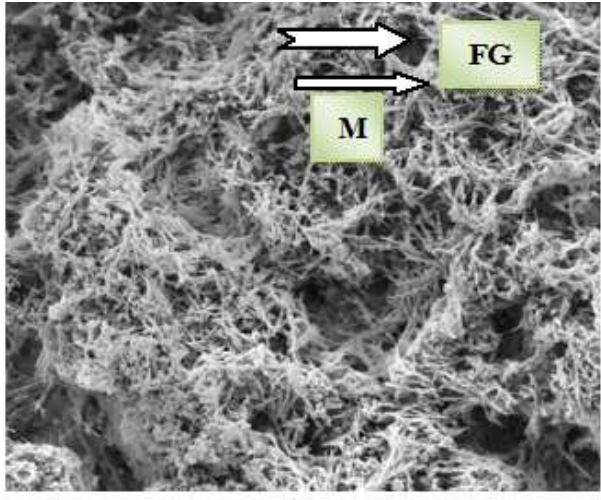

B

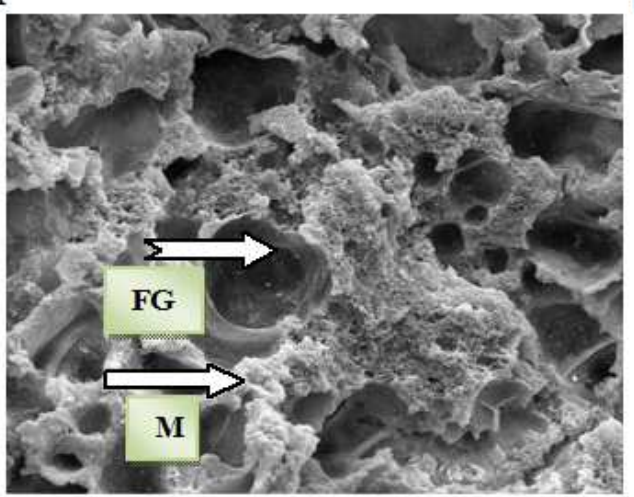

$\mathrm{C}$

Fig. 4. Microstructure of African catfish sausage (SEM: 2500X magnification). A. Smokeless sausage (control); B. Liquid smoked sausage ( $20 \%$ for 30 '); C. certain commercial smoked fish sausage, ( $\mathrm{M}=$ Myofibrils; $\mathrm{FG}=$ Fat Globules). 


\section{Discussion}

\subsection{Fat content of African catfish smoked sausage}

The results of the analysis of variance show that the treatment of liquid smoke concentration and immersion duration did not have a significant effect on sausage fat content with Duncan's test $(\alpha=0.05)$. The data in Table 1 shows the average results of varying fat content. Based on the results above, the differences in concentration of liquid smoke and immersion duration do not impact the fat content of smoked catfish sausage.

According to [6], fat is an organic compound that is insoluble in water but soluble in nonpolar organic solvents. As a result, the concentration of liquid smoke and immersion duration did not affect the fat content of sausages because the liquid smoke compounds could not dissolve non-polar fat. The fat content of smoked sausages was not highly different [25], which found that the fat content of African catfish sausages was in the range of $12.08-$ $15.94 \% \mathrm{dw}$.

The fat content in raw material obtained was $4.22 \%$, then after being processed into sausages, the fat content increased. This results is probably due to the impact of steaming and oven during processing. The heating treatment will reduce the water content, thereby increasing the fat and protein content. The maximum fat content of sausages based on SNI (Indonesian national standard) $01-3820-1995$ is $25 \%$, so the fat content of smoked African catfish sausages from this study still meets SNI standards.

\subsection{Protein content of African catfish smoked sausage}

The results of ANOVA show that the treatment of liquid smoke concentration and immersion duration the protein content of African catfish sausage did not have a significant effect among the treatments by Duncan's test $(\alpha=0.05)$, which is presented in Table 2 .

Table 2 shows that the results of the average protein content differ. This means that differences in the concentration of liquid smoke and immersion duration do not affect the protein content of smoked catfish sausage. The dominant compound in African catfish smoked sausage is a phenol that is polar and sausage protein. However, the compact shape of the sausage makes it difficult for liquid smoke to penetrate the protein in the sausage.

The protein content of African catfish meat initially ranged from $16.55 \pm 0.02 \%$. After being processed into sausage, the protein content increased in the range of $42.96-43.88 \%$. This condition may be caused, among others, by adding ingredients such as skim milk that can increase protein levels. According to [7], skim milk is one of the binders whose protein content is approximately $35 \%$. Another factor that can affect the increase in protein content is the effect of heat obtained at the time of steaming and heating in the oven during processing which will reduce the water content, thereby increasing the protein concentration.

Based on [5], the increased protein content of processed products compared to fresh products is due to the decrease in water content during the cooking process, which can increase the protein content of processed products. Heating with high temperatures will cause higher water loss so that it will increase the amount of fat, carbohydrates, and protein [26]. The results of the protein content of smoked African catfish sausages in this study still meet the quality standards determined by SNI $01-3820-1995$, which is $13 \%$ (the minimum limit of protein content in sausages). 


\subsection{Phenol content of African catfish smoked sausage}

Phenol compounds are predominant in smoked products because they play a role in contributing to the specific aroma and taste of smoked products [14]. This phenol analysis aimed to determine the number of phenolic compounds attached to smoked sausages. The average phenol content ranged from 234.92 to $366.81 \mathrm{ppm}$ or equivalent to $0.023-0.037 \%$. The results of ANOVA show that the treatment of liquid smoke concentration and immersion duration and their correlations have a very significant effect by Duncan's test $(\alpha=0.01)$.

Based on Table 3, the increase in the concentration of liquid smoke and immersion duration has a significant difference $(\alpha=0.01)$ with an increase in phenol content. This means that the concentration of liquid smoke increases, and the longer the sausage is immersed in liquid smoke increasing the phenol content of smoked sausage. Most of the compounds identified in the smoke component include phenol derivatives, acids, aldehydes, ketones, alcohol derivatives, and alkyl aryl ethers. Phenol levels will increase as the concentration of liquid smoke increases. The presence of phenolic compounds in liquid smoke provides antioxidant properties to the fat fraction in the smoked product. Determination of the best treatment was obtained from the total value of results at a concentration of $20 \%$ and 30 minutes of immersion with a score of 0.67 .

Phenol levels of smoked sausages in this study ranged from 234.92 to $366.81 \mathrm{ppm}$, not considerably different from the results of [26] research on beef sausage smoked using sawdust wood, which was $0.03 \%$ or equivalent to $300 \mathrm{ppm}$. According to [27], the main factors that determine the phenol content in smoked products are the smoking temperature, the concentration of liquid smoke added, and the smoking agent. The smoking material is directly related to the type of material consisting of hardwood or combustible materials, namely cellulose, hemicellulose, lignin, protein, and mineral compounds that can affect the presence of smoke, chemical compounds.

\subsection{Best treatment of African catfish smoked sausage}

Determination of the best treatment was carried out using the effective index method (Susrini, 2005). Total values from different concentrations of liquid smoke and immersion time are presented in Table 4 . The result shows that the best treatment combination was obtained from $20 \%$ liquid smoke concentration and 30 minutes of immersion.

\subsection{Component analysis of catfish smoked sausage using GC-MS}

The chromatogram of smokeless sausage (Figure 1A) showed that there were nine detectable peaks. Comparing the peak's mass spectra (chromatogram) with the spectra from the literature search was done to identify the compounds. The selected compounds are that have the highest SI (Similarity Index), with the assumption that these compounds have a considerable resemblance to the compounds present in smokeless sausages.

Table 5 shows that in smokeless sausages, nine compounds can be classified into acids, alcohols, ketones, carbonyls, and terpenes. The most dominant compound in the smokeless sausage was 2-hexanone, 3,3 dimethyl at peak number 6 with a relative concentration of $32.42 \%$. This compound is a ketone group. Ketones are classified as organic compounds containing a carbonyl group. A ketone has two alkyl groups attached to the carbonyl carbon. This ketone compound is a trigger for the oxidation process in fats [28]. The results of fat oxidation will produce peroxide, aldehyde, and ketone compounds. The smokeless sausage had a higher increase in peroxide value and TBARS than the best treated smoked sausages $[5]$. 
Table 6 shows that the best treatment of smoked sausage contained 14 compounds that could be classified into carbonyl, alkyl aryl ether, alcohol, ketone, phenol, furan, and terpene (patchouli alcohol). The dominant compound is furan, tetrahydro-2,2-dimethyl- with a relative concentration of $19 \%$. Furan is also known as furfuran, and furana is a kind of heterocyclic chemical compound. These compounds are generally derived from the thermal decomposition of wood-containing materials, are highly volatile, and have boiling points close to room temperature. Several compounds in liquid smoke appear in smoked sausages: alkyl aryl ethers, alcohols, phenols, ketones, and aldehydes. The phenol group compounds identified in the smoked sausages were the best treatment, namely Phenol, benzenol, oxybenzene; Phenol, 2-methoxy; -Phenol, 2,3-dimethyl- with a total relative concentration of $10.44 \%$. These phenol groups were detected in smoked sausages but not in smokeless sausages. This results is probably due to the phenolic compounds in the liquid smoke penetrating the smoked sausage. The ketone compounds in sausages without smoking were $50.49 \%$ reduced to $23.93 \%$ after the sausages were smoked. The decrease of ketones is probably due to the fat oxidation process in sausages. According to [29], fat oxidation results will produce peroxide compounds, aldehydes, and ketones. The smoked sausage tends to be less due to antioxidants in the smoke, which can inhibit the oxidation process.

\subsection{Catfish sausage microstructure}

Table 7 shows the range of moisture content, $A_{W}$, and texture of the three sausage samples examined for microstructure. The moisture content of commercial smoked sausage is $67.86 \%$, the value is greater than the moisture content of smokeless sausage and smoked sausage. While the moisture content of various trademarks in markets, according to [30], shows a range of 40 to $70 \%$.

The texture value indicates the level of hardness of the product. The lower the texture value, the more complex the product texture. This results is because during cooking will occur a gelatinization process that affects the texture of the product. According to [31], meat protein will shrink when heated, and starch molecules fill the cavities between protein threads. The formation of bonds between starch molecules and protein molecules can strengthen the texture.

The highest texture value was obtained in commercial smoked sausage, namely 2.95 $\mathrm{mm} / \mathrm{g}$.s. This results means that the texture of commercial smoked sausage is the softest among other samples. The $A_{W}$ values in the three samples showed a range of $0.85-0.88$. The lowest Aw levels were obtained from smokeless sausage samples, while the highest $A_{W}$ was in commercial smoked sausages. The water content is closely related to the $A_{W}$ value. The higher the water content, the higher the $A_{W}$ level.

Fig. 4 shows the microstructure of the three sausage samples in detail using a magnification of 2,500 times. Myosin threads are present in all forms of sausage microstructure due to damage to fish meat tissue cells because of mashing. Hence, their integrity is damaged due to the opening of the sarcolemma from myofibrils. In sausages, there are long threads called fibrils. The fibrils contained in the sausage microstructure cause free water in the sausage to flow and wet the surface that the sausage texture becomes soft and easily crushed.

The effect of smoking treatment during the study can be seen in the globules formed. Sausage microstructure globules in Figures 4B and 4C, namely the liquid smoking treatment of $20 \%$ immersion for 30 minutes and commercial sausage, have a smoother structure and more evenly distributed myofibril threads than Figure 4A, which is smokeless sausage. This value is probably due to the presence of terpene compounds (patchouli alcohol) in smoked sausages. 
The results of the GC-MS analysis showed that the terpene compound (patchouli alcohol) in the smoked sausage was greater than that of smokeless sausage, which was $9.16 \%$. According to [32], terpenoids compounds have oil-soluble properties (lipophiles). These properties cause the terpene compounds to sneak in between the cavities of the fat globules so that the structure looks smoother and flatter. The quality of sausage products depends on the matrix formed, especially the ratio of fat and protein [33, 34]. In the commercial smoked fish sausage (Fig. 4C), fat globules are seen, which are quite large compared to the fat globules of smoked sausages from this study. This results may be due to the different types of fish used, the composition of the binder and filler, and the different processing methods. In general, the sausages from this study have microstructures with smaller and finer globules than commercial smoked sausages. The diffusion of smoke components into the material depends on the thickness of the material, the concentration of liquid smoke used, and the immersion duration.

\section{Conclusion}

The characterization of the physical and chemical structures of African catfish smoked sausage with liquid smoke showed significantly different results. The physical structure was shown from the microstructure, and the myofibrils were getting denser and smoother with droplets of liquid smoke ( $20 \%$ concentration; 30 minutes). While the chemical structure was shown from the phenol content, which increases at a concentration of $20 \%$; the duration of immersion 30 minutes; average phenol $294.62 \mathrm{ppm}$ and 1\% DMRT.

\section{References}

1. Directorate-General for Aquaculture (DJPB), Strategic plan of the Directorate General of Aquaculture 2020-2024 (DJPB, Jakarta, 2020)

2. D.R.U.S. Rahayu, A.S. Piranti, I. Sihwaningrum, Dinamika. J. 1, 1 (2019)

3. I. Zuraida, R. Hasbullah, Sukarno, S. Budijanto, S. Prabawati, Setiadjit, J. Agric. Sci. 14, 1 (2009)

4. Siswanti, H. Herawati, Rahmayuni, Japanese J. Allergol. 44, 8 (1995)

5. A.K. Nisa, A.K. Wardani, J. Pangan dan Agroindustri 4, 1 (2016)

6. Y. Ibrahim, I.K. Suwetja, F. Mentang, Aquat. Sci. Manag. 4, 1 (2016)

7. M. Srimiati, C.M. Kusharto, I. Tanziha, S.H. Suseno, J. Gizi dan Pangan 12, 2 (2017)

8. N. Montazeri, A.C.M. Oliveira, B.H. Himelbloom, M.B. Leigh, C.A. Crapo, J. Food Sci. Nutr. 1, 1 (2013)

9. T. Pasaribu, E. Wina, National Seminar Proceedings TPV, 679-685 (2017)

10. M.D.C. Surboyo, I. Arundina, R.P. Rahayu, D. Mansur, T. Bramantoro, Eur. J. Dent. 13, 2 (2019)

11. S. Saloko, P. Darmadji, B. Setiaji, Y. Pranoto, J. Food Biosci. 7, 71-79 (2014)

12. A.C. Imaniar, I.L. Vidyahayati, G. Wibisono, V.R. Ciptaningtyas, G. Pulpa, J. Kedokt. Diponegoro 7, 2 (2018)

13. N. Vieco-saiz, Y. Belguesmia, R. Raspoet, E. Auclair, F. Gancel, I. Kempf, D. Drider. Front. Microbiol. 10, 57 (2019)

14. P. Visciano, M. Perugini, M. Amorena, A. Ianieri, J. Food Prot. 69, 5 (2006)

15. S. Barbut, Texture analysis (CRC Press, Washington DC, 2010)

16. S.R. Nayak, R. Padhy, J. Mishra, J. Adv. Res. Dyn. Control Syst. 9, 11 (2017) 
17. I. Matulyte, M. Marksa, L. Ivanauskas, Z. Kalvenien, R. Lazauskas, J. Bernatoniene, J. Molecules 24, 6 (2019)

18. A.M. V, "Gas chromatography-mass spectrometry for the analysis of metabolomic compounds in agrifood products. New methods and applications (Universitat de Lleida, Lleida, 2017)

19. K. Sirivibulkovit, S. Nouanthavong, Y. Sameenoi, Anal. Sci. 34, 7 (2018)

20. L. Leaves, Orient. 1, 4 (2014)

21. M.A. Adam, M. Maftuch, H. Hardoko, Nat. B. 2, 1 (2013)

22. W. Horwitz, W.G. Latimer, Official methods of analysis of AOAC international (AOAC International, Gaithersburg, 2005)

23. M.A. Adam, M. Maftuch, Y. Kilawati, Y. Risjani, Egypt. J. Aquat. Res. 45, 4 (2019)

24. K. Mittendorf, L. Hollosi, E. Ates, K. Bousova, Determination of Polycyclic Aromatic Hydrocarbons (PAHs) and aliphatic hydrocarbons in fish by GC-MS/MS (Thermo Fisher Scientific, San Jose, 2010)

25. M.U. Effiong, C.A. Yaro, Aquac. Stud. 20, 1 (2020)

26. F. Swastawati, T. Surti, T. Agustini, P. Riyadi, 1st Int. Symp. Aquat. Prod. Process. 2013, 1 (2015)

27. R. Eisler, Polycyclic aromatic hydrocarbon hazards to fish, wildlife and invertebrates: a synoptic review (US Department of the Interior, Fish and Wildlife Service, Laurel, 1987)

28. J.E. Ross, N.E. Scangarella-Oman, R.K. Flamm, R.N. Jones, J. Clin. Microbiol. 52, 7 (2014)

29. A. Kolalowska, Lipid oxidation in food systems (CRC Press, Washington DC, 2003)

30. M. Kodra, Ariola D, Dhurata F, M. Stafasani, S. Edlira, J. Hyg. Eng. 496, 5 (2020)

31. S. Basak, G.F. Şengör, F. T. Karakoç, Turkish J. Fish. Aquat. Sci. 10, 3 (2010)

32. D.A. Dipowaseso, N. Nurwantoro, A. Hintono, J. Teknol. Pangan 2, 1 (2018)

33. I. Mulyawanti, S.I. Kailaku, A.N.A. Syah, Risfaheri, IOP Conf. Ser. Earth Environ. Sci. 309, 1 (2019)

34. E. Ernawati, J. Kelaut. Indones. J. Mar. Sci. Technol. 8, 2 (2015) 